\title{
最新の高圧凍結装置とアプリケーション
}

\author{
伊藤喜子 \\ ライカマイクロシステムズ株式会社 テ108-0072 東京都港区白金1-27-6 白金高輪ステーションビル 6F
}

要旨 :一般的な電子顕微鏡用試料の前処理では, 化学固定およびそれに続く脱水, 置換の過程で細胞の微細構造変化や可溶 性成分の流出などのアーティファクトが生じることが知られている。これを解決する手法として，細胞の状態を瞬時に止めることので きる凍結固定法が提唱されている. 通常, 水は凍る際, 結晶化して細胞内で水晶が形成される. この際, 微細構造の破壊が起 きる，そこで，電子顕微鏡観察レベルで構造を保持するためには，水を非晶質に凍結する必要がある．凍結手法には大気圧下 で試料を急速に冷却する急速凍結法と，2100 bar (210 MPa) の圧力下で凍結する高圧凍結法がある. 急速凍結法では非晶質に 凍結できる深さが約 5 20 $\mu \mathrm{m}$ であるのに対し，高圧凍結法では約 $200 \mu \mathrm{m}$ と言われており，植物等のやや大きめな細胞，さらに 組織レベルでの解析にも大いに役立つ手法となっている．凍結固定後のワークフローは，凍結状態で固定脱水を行った後，樹 脂包埋および薄切して観察する凍結置換法と，凍結状態の試料をそのままクライオミクロトームで薄切して，cryo-TEMで観察する CEMOVISなどがある. また, 凍結試料の凍結切削した断面をcryo-SEMで観察する試みもなされている. 本総説では, 高圧凍 結の最新情報とそのアプリケーション例を紹介する.

\section{The latest high pressure freezing systems and their applications}

\section{Yoshiko Ito}

Leica Microsystems K.K., Shirokane-takanawa Station Bldg. 6F, 1-27-6 Shirokane, Minato-ku, Tokyo, 108-0072 Japan Author for correspondence: Y. Ito, yoshiko.ito@leica-microsystems.co.jp

Summary: The conventional sample preparation for electron microscopy makes the artifacts in the process of dehydration and substitution, such as the changes of ultrastructure of cells and outflow of soluble components in the cells. Cryofixation has been proposed as the method to overcome the inconvenient and unexpected problems, by freezing the cells very rapidly. Because water freezes to be ice crystals with increase of the volume, and those formed in the cells destroy the ultrastructure. To preserve the ultrastructure of native cells at the resolution of electron microscopic level, it is required to make amorphous ice at the process of cryofixation. As the methods for it, rapid freezing to cool samples rapidly in normal pressure and high pressure freezing to freeze under 2100 bar have been proposed. In this review, the information of the latest high pressure freezing systems and their application has been introduced. The depth of good freezing in amorphous ice made by rapid freezing is 5 to $20 \mu \mathrm{m}$, on the other hand, that of high pressure freezing is about $200 \mu \mathrm{m}$. So the high pressure freezing can be applied for the electron microscopic analyses of cells and tissues at closed-to-native state. Workflows after cryofixation are, for example, freeze substitution and cryo-TEM observation of vitreous ice sections, or CEMOVIS. Furthermore, the surface of cryo-sectioned frozen samples has been observed by cryo-SEM.

Key words: electron microscopy, high pressure freezing, freeze substitution, CEMOVIS, CLEM, cryo-SEM

\section{はじめに}

生物試料を透過型電子顕微鏡 (TEM) で観察する一般的な 手法として，高真空，電子線衝撃に耐えられるようにする事を 目的に樹脂包埋法が用いられている. しかし，化学固定および これに続く脱水, 熱重合の過程で, 細胞の微細構造に様々な アーティファクトが生じることも示唆されている，例えば, 細胞成 分が流出したり, タンパク質の修飾や分解によって構造および 抗原性が変化したり寸ることが知られている. そのため, 酵素 活性や抗体標識によるタンパク質の細胞内局在の解析, 細胞 内イオン局在の正確な解析は困難である. この問題を解決する ひとつの手法として, 凍結固定法が提唱されている. 化学固定 法と凍結固定法の比較を図 1 に示す. 凍結固定 (この例では, 高圧凍結法)した試料では化学固定した試料に比べて, 細胞 膜の凹凸が無くスムースで, 脂質二重膜が明瞭に観察されるな ど, 明らかな違いが見て取れる. その他, 様々な所見から細胞 が生きていた時に近い状態で保持されていると言える.
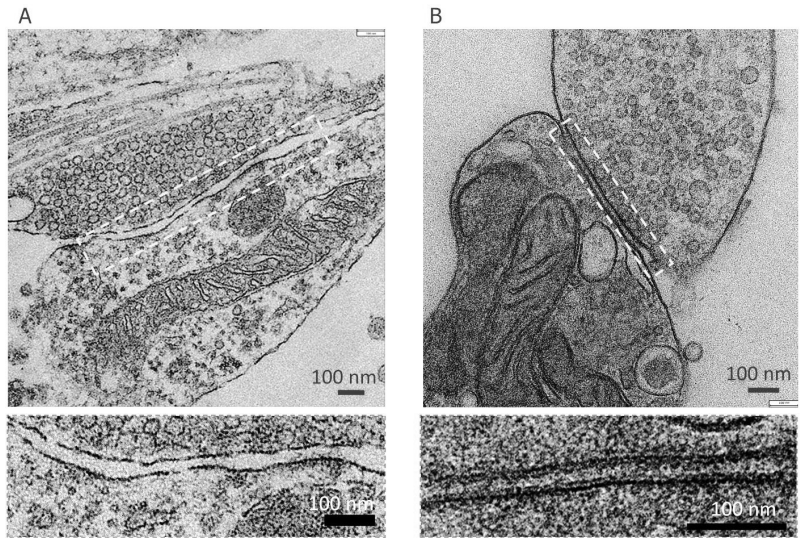

図 1 固定法による微細構造保存性の違い. ラット海馬初代培養細胞 を化学固定法 (A) および高圧凍結・凍結置換法 (B) で調製した。そ れぞれ上図の破線で囲んだ領域の高倍率像が下図である. 


\section{凍結技法概要}

凍結固定では水を含む全ての細胞構成要素を保存すること ができる. しかし, 水晶形成による構造アーティファクトが問題 となる. 水は大気圧下で凍ると, 結晶性の水に転移し流動性 を失う. 常圧下で $0^{\circ} \mathrm{C}$ ま゙冷却された水は, 分子間に規則的 な水素結合を持つ六方晶の結晶に形成される. 水は, 代表 的な異常液体であり, 結晶状態の構造には内部に大きな空間 があるため液体状態 $\left(4^{\circ} \mathrm{C}\right)$ より体積が $9 \%$ 増加する. そのため, 細胞内で水晶が形成されると, 水の移動や膨張により細胞の 微細構造が破壊されてしまう。これは電子顕微鏡の解像度で は重大な損傷として観察される (図 2). そこで, 微細構造観 察における生物試料の凍結固定では, 水晶が形成されにくい 条件下での凍結が不可欠である. 装置的に大別すると急速凍 結法と高圧凍結法の 2 種類がある. 急速凍結法は大気圧下で $10^{4} \mathrm{~K} / \mathrm{sec}$ 以上 (純水の場合 $10^{6} \mathrm{~K} / \mathrm{sec}$ 以上) の速度で試料を冷 却する方法で (Dubochet et al. 1988), この中でも浸漬法と金 属圧着法が広く用いられている (Heuser et al. 1979, Sitte et al. 1987).

弊社では浸漬法・金属圧着法向けとして急速凍結試料作製 装置EM CPCを, 浸漬法専用機として環境制御型自動浸漬凍 結装置EM GP(Resch et al. 2011) を提案している. 浸漬法は試 料を冷媒中に急速に投げいれることで凍結を行う. 装置の冷却 などでよく用いられる液体窒素は, 融点 $\left(-210{ }^{\circ} \mathrm{C}\right)$ と沸点 $(-196$ $\left.{ }^{\circ} \mathrm{C}\right)$ が近い (表 1)。凍結温度として有効であるが, 試料を液体

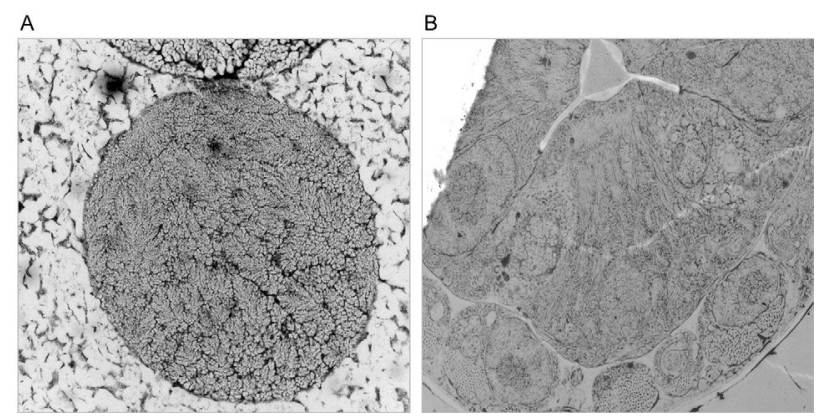

図 2 氷晶による微細構造の破壊. A. 大気圧下で涷結した赤血球, B. C.elegans
窒素に浸漬するとすぐ沸騰し, なかなかおさまらない.このとき， 試料周囲には窒素ガス層が形成されているため, 沸騰がおさ まるまで試料表面に液体窒素が触れず冷却効率が悪い緩慢凍 結となってしまう。 そこで, 浸漬法の冷媒としては, 融点と沸点 の差が大きい液体エタン (特に生体分子の水包埋), 液体プロ パン (細胞等の凍結) が用いられている. また, 大気圧化で涷 結効率が最も良いとされる金属圧着法は, 熱伝導率の高い純 銅ブロックを鏡面研磨し，酸化被膜付着防止の金メッキを施し た金属ブロックを液体窒素 (または液体へリウム) 温度まで泠却 し，ブロック表面に試料を圧着することで冷却を行う．ただ，液 体窒素を用いた金属圧着法で非晶質水層は水を含む表面から 約 $10 \mu \mathrm{m}$, 浸漬法では 約 $5 \mu \mathrm{m}$ と言われている. 細胞の平均 的な大きさから考えると, 凍結深度が小さい.

これに対して, 高圧凍結法だが，水は $210 \mathrm{MPa}$ では - $90^{\circ} \mathrm{C}$ まで過冷却できる (Kanno et al. 1975)。また，この圧力下では 水は高粘度になり流動性が下がるため, 結晶の形成速度が低 下し, 凍結速度が大気圧下での浸漬凍結法と比較して遅くなっ ても, 氷晶形成を抑えることができる. この性質を利用した のが高圧凍結法である (Moor 1987, Studer et al.1989). 高 圧凍結法では非晶質凍結深度が約 $200 \mu \mathrm{m}$ と報告されており (Studer et al. 1989), 細胞壁や大型の細胞などもある植物, さ らに組織レベルでの解析に大いに利用できる可能性を持つ(Dahl and Staehelin 1989, 菅沼 1997, Osumi 2012). 弊社は高圧凍 結装置としてEM PACT2，EM HPM100，およびEM SPFを提 案している.

\section{最新の高圧凍結装置}

高圧凍結装置は，加圧と液体窒素による冷却をミリセカンド 内でシステム化し, 試料装填から凍結済及試料の回収を安全 に再現性よく行えるようにしたものである，加圧方式には，A： インナープレッシャー方式と, B : アウタープレッシャー方式が ある(図3).

弊社のEM PACT2 は加圧方式Aを, EM HPM100は加圧 方式Bを採用している. また, EM SPFは自己加圧方式という 加圧方式Aの変法を採用した装置である.

EM PACT2 は圧力伝達液 (通常メチルシクロヘキサン)を介 した加圧 $(210 \mathrm{MPa})$ と連動して， 試料に液体窒素のジェット流 $(10$ 表 1 各種冷媒の物性

\begin{tabular}{|c|c|c|c|c|c|c|}
\hline & $\begin{array}{l}\text { ETHANE } \\
\text { I文 }\end{array}$ & $\begin{array}{l}\text { PROPANE } \\
\text { JロIYン }\end{array}$ & $\begin{array}{c}\text { ISOBUTANE } \\
\text { イソフタン }\end{array}$ & $\begin{array}{l}\text { ISOPENTANE } \\
\text { イソハンタン }\end{array}$ & $\begin{array}{l}\text { NITROGEN } \\
\text { 空素 } \\
\end{array}$ & $\begin{array}{l}\text { HELIUMU } \\
\text { NJウҢ }\end{array}$ \\
\hline 分子式 & $\mathrm{C}_{2} \mathrm{H} \delta$ & $\mathrm{C}_{3} \mathrm{H}_{8}$ & $\mathrm{i}-\mathrm{C}_{4} \mathrm{H}_{10}$ & $\mathrm{i}-\mathrm{CsSH}_{12}$ & $\mathrm{~N}_{2}$ & $\mathrm{He2}$ \\
\hline 分子里 & 3007 & 44.1 & 58.12 & 72.15 & 2801 & 4003 \\
\hline 点 ("C) (101.32kPa) & -1833 & -187.7 & -159.6 & -1599 & -210 & -272.2 \\
\hline 沸点 ("C)(101.32kPa) & -88.5 & -42.1 & -11.7 & 278 & -1958 & -26893 \\
\hline 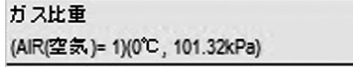 & 1038 & 1522 & 2066 & 2.49 & 0967 & 0.1381 \\
\hline 臨界温度("C) & 32.4 & 968 & 135 & 187.2 & -1469 & -26796 \\
\hline 臨界压 (MPa) & 4.73 & 4.12 & 353 & 3.23 & 3.29 & 0.227 \\
\hline $\begin{array}{l}\text { 荥発潜聲 } \\
\text { (KJ/Kg)(BOILING POINT(沸点) 101.32kPa) }\end{array}$ & 4893 & 425.7 & 366 & 342 & 204 & 20.4 \\
\hline 気体密度 $(\mathrm{kg} / \mathrm{m} 3)\left(0^{\circ} \mathrm{C}, 1 \mathrm{gtm}\right)$ & 1357 & 201 & 2.76 & 30514 & 1.251 & 0.1785 \\
\hline 液体密度 (KE/L) (弗点) & 0.546 & 0.582 & 0.601 & 05245 & 0806 & 0.125 \\
\hline 㙋発限界 \%(空気中) & $3 \sim 125$ & $2.2 \sim 95$ & $19 \sim 85$ & $13 \sim 80$ & (不活性) & (不活性) \\
\hline 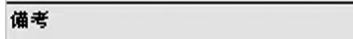 & 無色無宾 & 無色無实 & 無色わずか实 & 無色無实 & 無色無实 & 無色無茣 \\
\hline
\end{tabular}
bar）を吹き付ける. 試料キャリ アー内だけのピンポイントの加 圧となるため比較的コンパクト な装置サイズに設計でき, キャ スターに載せる事でバリアフ リーな実験室内では, 移動が 容易となっている $($ W910mm $\times$ $\mathrm{D} 630 \mathrm{~mm} \times \mathrm{H} 930+890 \mathrm{~mm}$, 本 体の夕重量 $99 \mathrm{~kg}$ )。凍結の際, 平板試料キャリアーは図 $3 \mathrm{~A} の$ ように試料ポッド内に固定され ている. 左側が底, 右側が試 料となっており, 圧力伝達液は 試料キャリアーの底にある小孔 を介して試料キャリアー内部に 圧力を加える. 本装置は直径 $1.5 \mathrm{~mm}$ 以下, 厚さ $200 \mu \mathrm{m}$ 程度 
の試料を凍結することが可能である. 他にも多様な試料キャリ アーが女り，様々な目的に対応している(図4)。図4Aは組織 (植物の葉など) の凍結向けの平板試料キャリアーである. また, 懸濁試料を吸引して凍結する銅製の試料チューブ (内径 350 $\mu \mathrm{m})$ もある. 桿菌等を試料チューブに詰めると長軸方向に揃っ てしまうことがある.これを避けたい場合, メンブレンキャリアー(図 4B）を用いる. その他フリーズ・フラクチャ用 (図4C), biopsy 用 (図4D)などのキャリアーがある.

EM HPM100が採用している 加圧方式Bでは液体窒素の ジェット流を吹き付けることでキャリアー外から加圧しながら冷 却を行う (図3B). 図3Bでは, ミドルプレート内に, 2枚の平 板試料キャリアー(図6Aタイプ) で試料をサンドイッチして格納 し, 浅い溝が彫ってあるハーフシリンダーで上下を挟むことでキャ リアーの上下に液体窒素の流路を作っている．ちょうど円筒形 になるよう 3 パーツを合わせ, 本体に装填する. 圧力伝達まで の空間密閉の媒体としてエタノールを自動装填し, 続いてコン プレッサーで加圧した液体窒素がジェット流となってシリンダー 内の 2 本の流路を流れ, 加圧と凍結を行う. 動水圧と同様, 流れ方向に対して垂直に圧力が加わる. この圧力は液体窒素 の単位面積当たりの運動エネルギーに等しい. これにより試料 キャリアーへの $210 \mathrm{MPa} の$ 加圧を実現している.

この方式のメリットはより広い試料に対応可能な点である. 本装置では最大直径 $5 \mathrm{~mm}$ の試料まで凍結可能であり, 組織 のよりワイド領域へと応用が広がっている. しかしながら, 加 圧メカニズムが最も大型となるため比して装置サイズも大きい $(\mathrm{W} 713 \mathrm{~mm} \times \mathrm{D} 1364 \mathrm{~mm} \times \mathrm{H} 1283 \mathrm{~mm} ， 340 \mathrm{~kg})$ ．キャスターも 搭載しているが装置可動性はあまり考えない方が良いだろう。 HPM100の試料キャリアーは2つ1組となった 2 枚貝のような
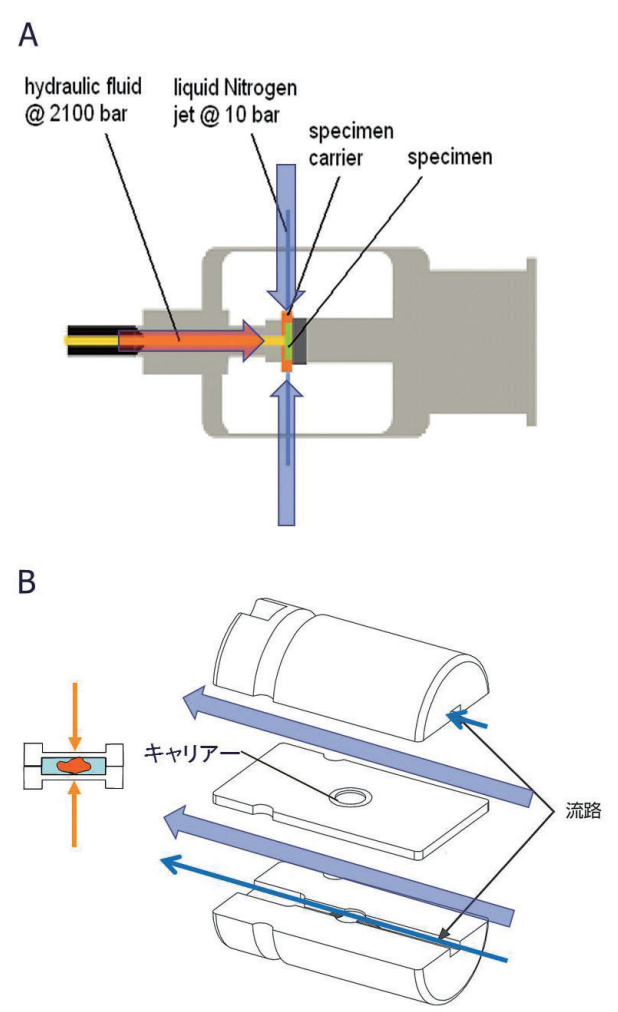

図3 高圧凍結装置の加圧方式．A. インナープレッシャー方式, B.ア ウタープレッシャー方式

弊社の高圧凍結装置EM PACT2ではAを, EM HPM100ではBを採用.
構造になっており，その間に試料を装填する(図 5). 目的に 合わせ 20 種程度あり，ここでは，代表的なものを例にあげる. 平板試料キャリアーには外径 $3 \mathrm{~mm}$ と $6 \mathrm{~mm}$ の 2 種あり, 図6で は，外径 $3 \mathrm{~mm}$ のものをあげる．図6A，Bに示すように平板試 料キャリアーには，上下・片面に様々な深さがあり，径が同じ もの同士は上下組み合わせ可能である. また, フリーズフラクチャ
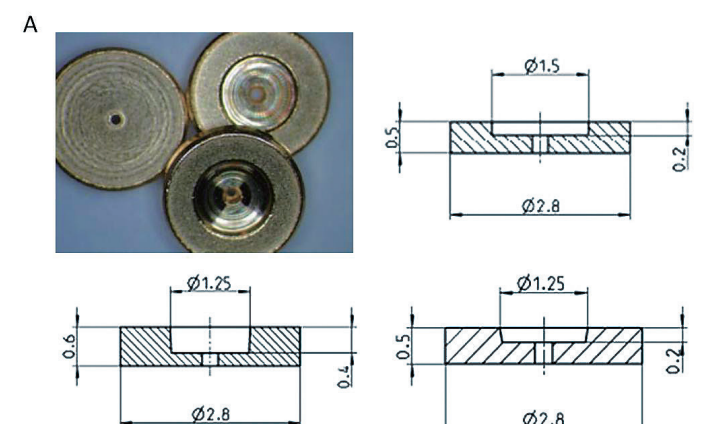

B
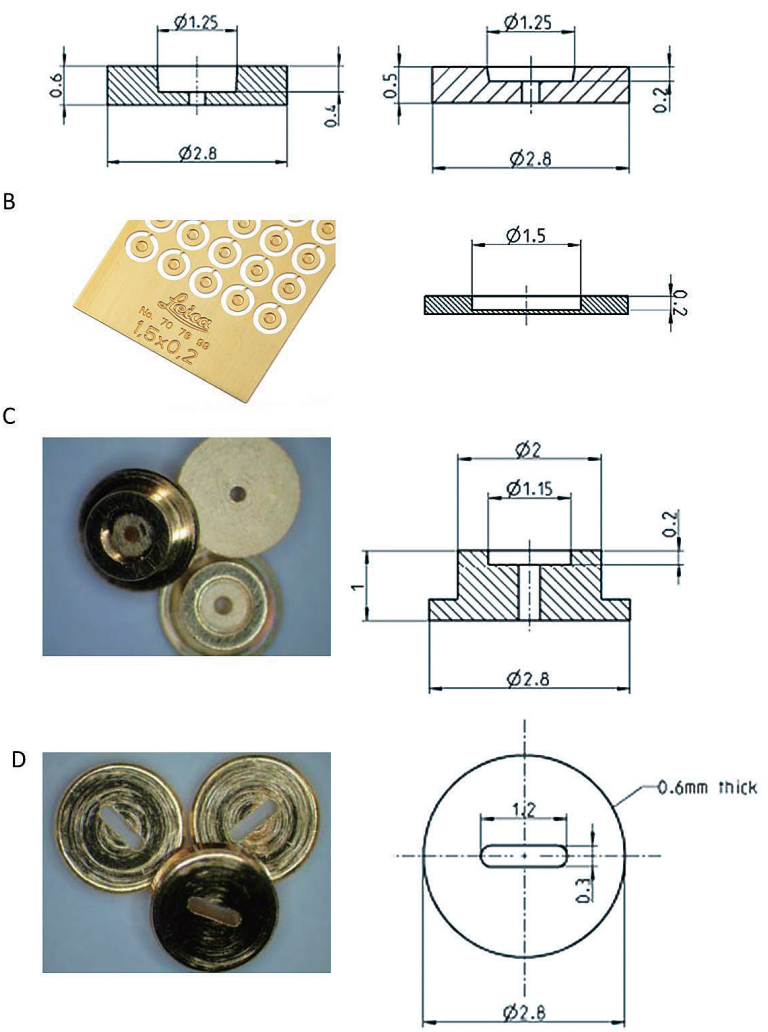

図 4 EM PACT2の試料キャリアー。A. 平板試料キャリアー，B．メンブ レンキャリアー, C. フリーズフラクチャ用キャリアー, D. biopsy 用キャリアー。 メンブレンキャリアーにはくぼみの深さが $0.1 \mathrm{~mm}$ のものと $0.2 \mathrm{~mm}$ のも がある.

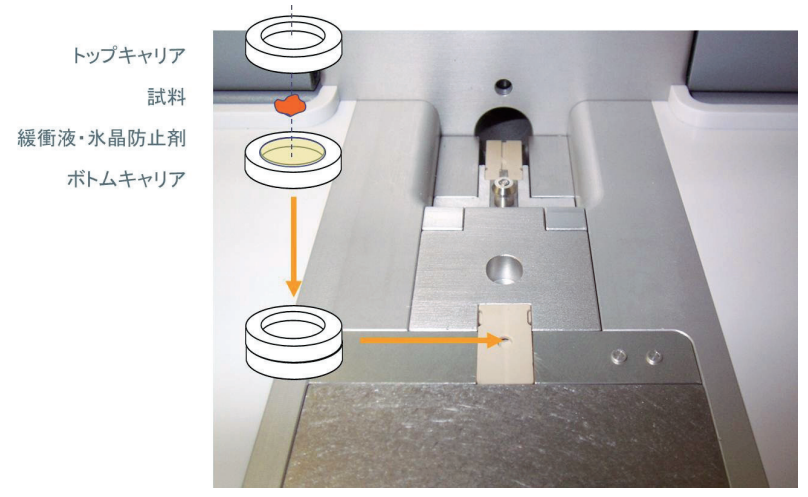

図 5 EM HPM100 の試料装填方法

ボトムキャリアーの中に緩衝液 (水晶防止剂は添加してもしなくてもよい) と試料を入れ，トップキャリアーで蓋をする。緩衝液がキャリアーからあ ふれたり, キャリアーのくぼみに気体が入らないよう注意する. 
用としてシリンドリカル型(図6C), ドーム型(図6D), およびフラッ トトップ型(図6E)の3 種類のキャリアーがある. こちらも平板キャ リアー同様, フリーズ・フラクチャ用キャリアー同士なら目的に 合わせて組み合わせ可能である.

加圧方式Aの変法として, 自己加圧式の凍結法が提唱さ れ (Leunissen and Yi 2009), EM SPFを製品化した. 加圧 メカニズムを持たないため装置サイズが小さく $(\mathrm{W} 800 \mathrm{~mm} \times$ $\mathrm{D} 1200 \mathrm{~mm} \times \mathrm{H} 900 \mathrm{~mm}$, 重量 $70 \mathrm{~kg}$ ) 高圧凍結装置としては比 較的安価である. しかしながら，本手法では，チューブ状キャ リアに装填できる試料のみ凍結可能となるため懸濁試料など小 さな試料に限定して有効である.U字型の銅チューブに懸濁
A

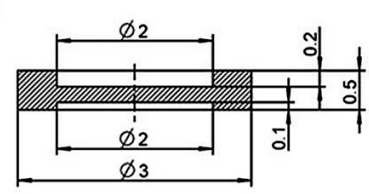

C

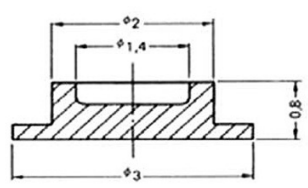

E

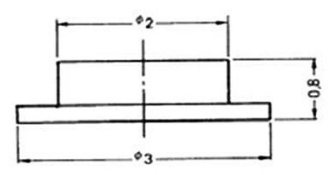

B

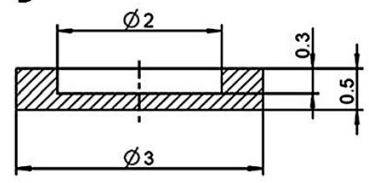

D

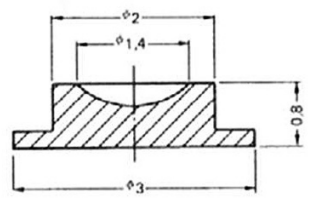

図 6 EM HPM100試料キャリアー

平板試料キャリアーには表裏両側にくぼみがあるタイプ (A) と片側のみ くぼみがあるタイプ (B) がある. それぞれくぼみの内径が $2 \mathrm{~mm}$ と $5 \mathrm{~mm}$ がある. フリーズフラクチャ用キャリアーはシリンドリカル型 (C) とドー ム型 (D)，およびフラットトップ型 (E) がある. それぞれ内径 $2 \mathrm{~mm}$ と 5 mmがある.
試料を装填し, 端を密封する. このUチューブの両端のみを 液化プロパンに浸漬し泠却すると, 両端で水晶が形成され水 分が膨張しチューブ中央のカーブしている部分で内圧が上昇 する (図7)。この後, Uチューブ全体を冷媒に投入する. U チューブ中央部では試料溶液が加圧凍結されることになる。 本装置では, この一連の作業の再現性を確保するため, 冷媒 の温度管理，凍結ごとの冷媒から試料までの高さ測定や，予 冷及び浸漬加圧凍結までのタイミング調整が自動化され，冷 却窒素ガスで温度コントロールされたクライオチャンバー内では, 銅チューブの切出しなどが行える治具が内蔵されている.

\section{凍結後のアプリケーション1－凍結置換法, CLEM}

凍結固定後のアプリケーションは様々な手法 (図 8) が提 案されている, ここでは最もポピュラーな凍結置換法, その 中からCLEMに関してと, 最新の凍結切削テクニックとして CEMOVIS, さらに, cryo-SEM法について述べる（その他の 総説として伊藤と宮澤 2010).

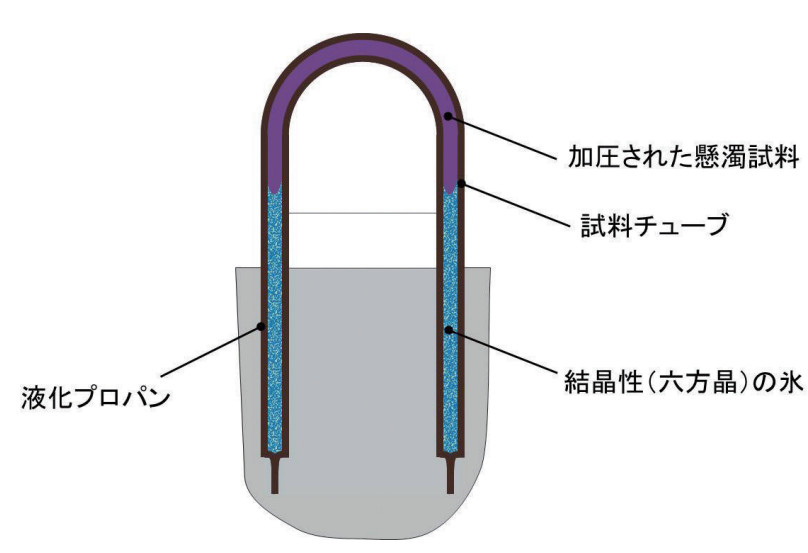

図7 EM SPFにおける凍結

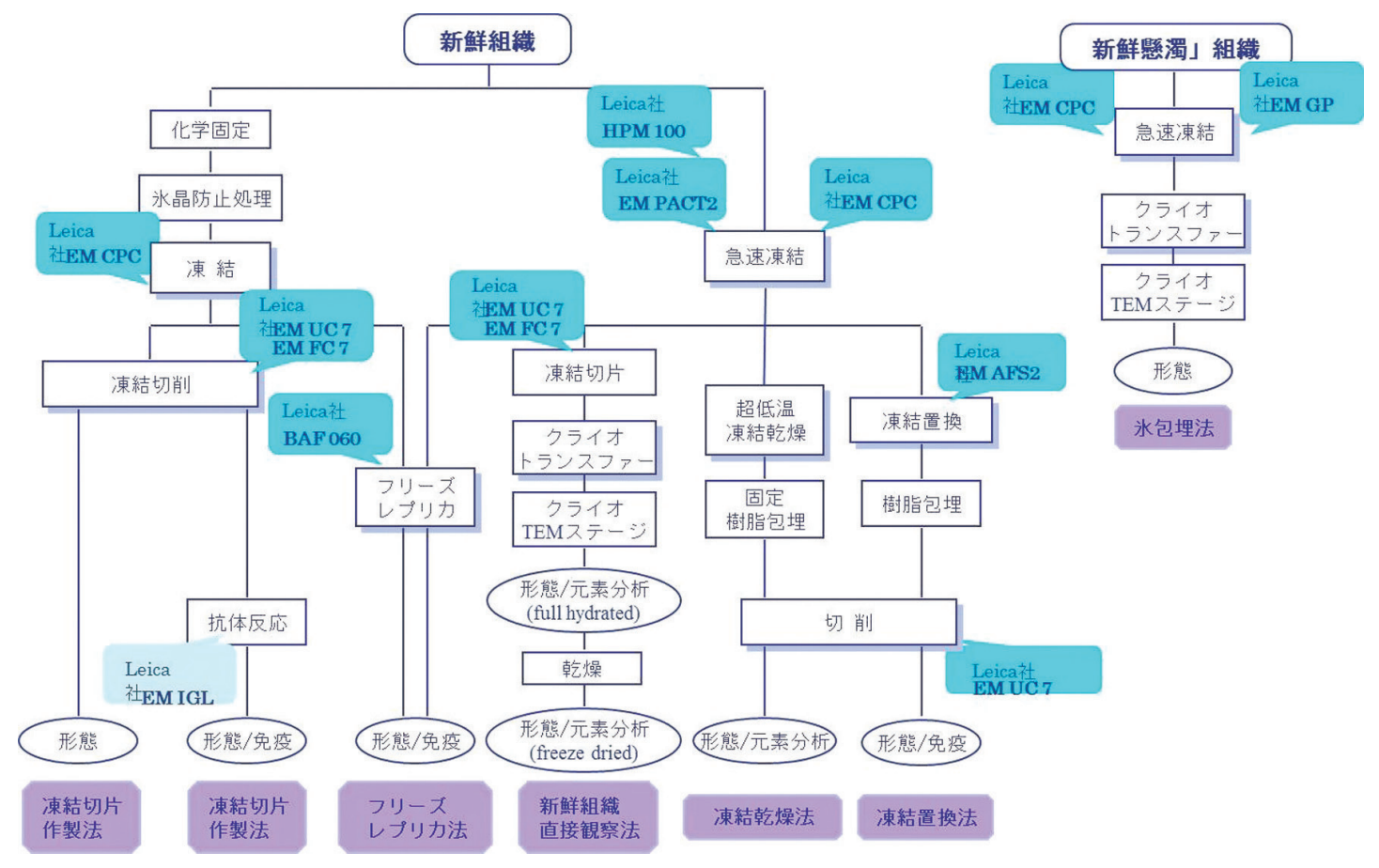

図8 凍結固定後のアプリケーション 
凍結置換法では細胞が凍結した状態で固定と脱水を行うため, 脱水による細胞成分の流出や微細構造変化が最小限に抑え られると言われている. そのため, 形態学的な研究はもちろん, 免疫細胞化学的手法による生体物質の局在解析にも最適であ る. 弊社では凍結置換法に必要な温度環境コントロールを自 動で行うEM AFS2 を提案している. これにはオプションで冷却 環境下でのテイッシュプロセッサーであるEM FSPを取り付けら れる. 試薬をセットしておけば，入れ替えや希釈が自動で行 われる. さて, 凍結置換法だが，凍結した試料を $-90 \sim-80^{\circ} \mathrm{C}$ の置換溶媒に入れ脱水を行い, 徐々に昇温して樹脂包埋を 行う. 置換液は, 目的に合わせ, 構造解析を中心とするなら 2 4\% 四酸化オスミウム・アセトンを用い, 免疫電子顕微鏡 法向けには, メタノール・ウラン溶液など化学固定剤を含まな い置換液(または, ごく低濃度の化学固定剂入り)を用いて脱水・ 置換を行う，樹脂も同様で，微細構造観察の場合は，室温ま で昇温した後，一般的なエポキシ樹脂包埋をすると良いだろ う。しかし，免疫電子顕微鏡法では，エポキシ樹脂は，抗体 の反応性が悪く非特異反応も起きやすいため, 低温下で紫外 線重合が出来るLR系, Lowicryl 系の樹脂を用いる報告が多い. 目的に応じてこれらを組み合わせて選択をすると良いだろう(な お，ここでは割愛するが，凍結置換法の各論に関しては，多 くのすぐれた書籍・報告がある. それらを参照されたい).

また, 近年, 光学顕微鏡 (蛍光顕微鏡) と電子顕微鏡で同 じ領域を観察するCLEM（相関顕微鏡法 ; Correlative Light

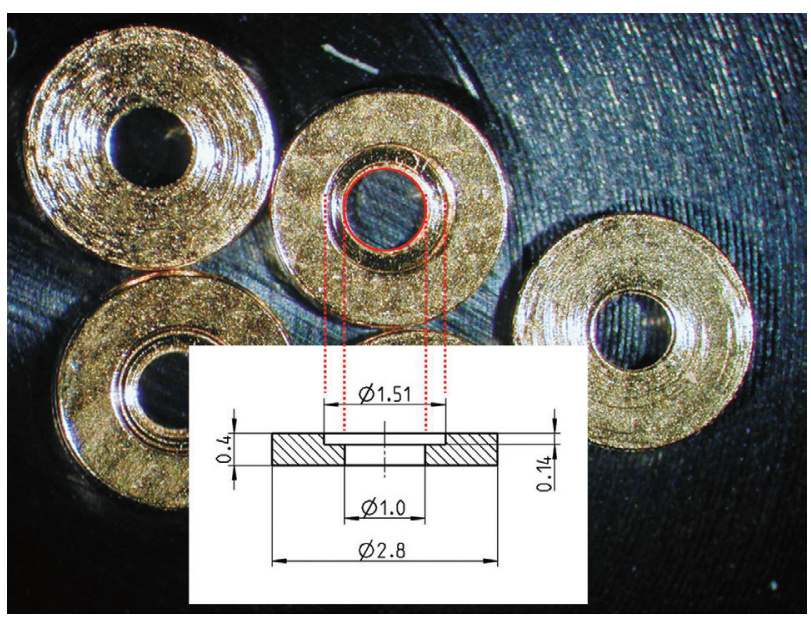

図9 Live Cell キャリアー

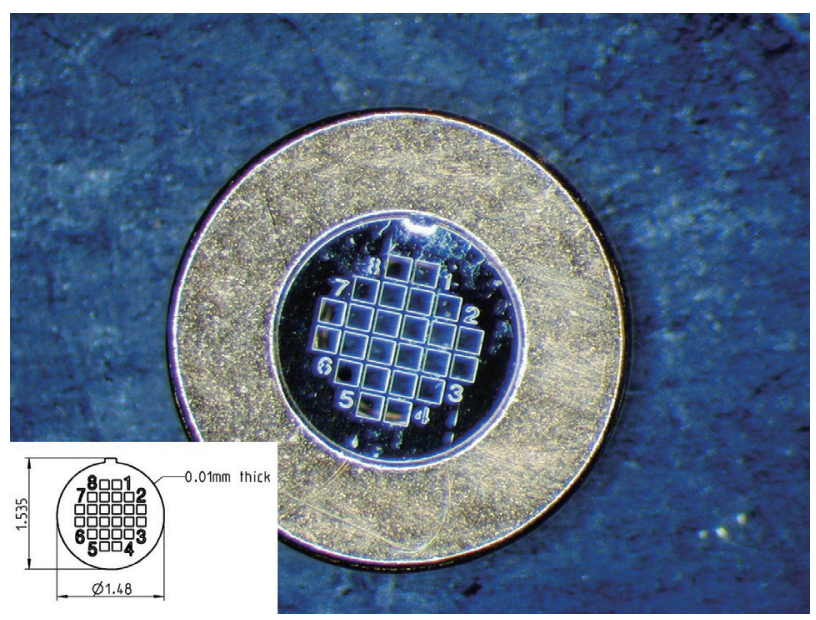

図 10 Live Cell キャリアーにファインダーグリッド $(\mathrm{Ni})$ をセットしたところ and Electron Microscopy) が注目されている. 生きたまま細胞 を観察できる光学顕微鏡にて低倍広視野で目的領域 (例：特 定のタンパク質が集積している部分) を特定した後, 電子顕微 鏡でその領域を高解像度で観察する. しかし, 一般的な光学 顕微鏡像と電子顕微鏡像とでは倍率のギャップが大きく, 電子 顕微鏡で目的領域を見つけるにはこれらの橋渡しが必要である. 弊社の高圧凍結装置EM PACT2およびEM HPM100にはそ れぞれソリューション方式のCLEM 用アクセサリーであるLive CellキットおよびCLEMシステムがある.ここではEM PACT2 を用いた手法について紹介する(Verkade 2005，2009). Live CellキットはLive Cellキャリアー(図9) とサファイアディスク（直 径 $1.4 \mathrm{~mm}$ ) と $\mathrm{Ni}$ 製のファインダーグリッド(直径 $1.48 \mathrm{~mm}$ ) から 構成される. Live Cell キャリアーは中央に直径 $1.5 \mathrm{~mm}$ のくぼ みと直径 $1 \mathrm{~mm}$ の穴がある. Live Cellキャリアーのくぼみに細 胞を播種したサファイアディスクとファインダーグリッドをはめて （図 10）蛍光顕微鏡で観察し, 目的領域を特定する. ファイン ダーグリッドの番地を見て，その領域がどの番地にあるのか確 認しておく. この試料を高圧凍結-凍結置換し，樹脂包埋す る(図 11)，樹脂ブロックからキャリアーとサファイアディスクを 除去すると, 細胞層とファインダーグリッドが樹脂ブロックに残 る. サファイアディスクにカーボン蒸着しておくと, 細胞層を樹 脂ブロック側に残してサファイアディスクのみ剥離しやすくなる. 実体顕微鏡下でファインダーグリッドの番地をもとに目的領域 を狙ってトリミングし (図 12) 超薄切片を作製することで, 光学

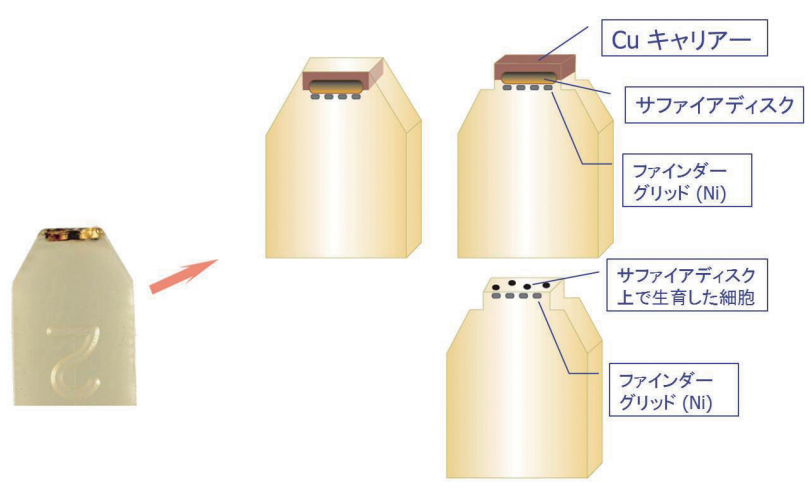

図 11 Live Cell キャリアー・システムの樹脂包埋後のトリシングとキャリアー の取り外し手順
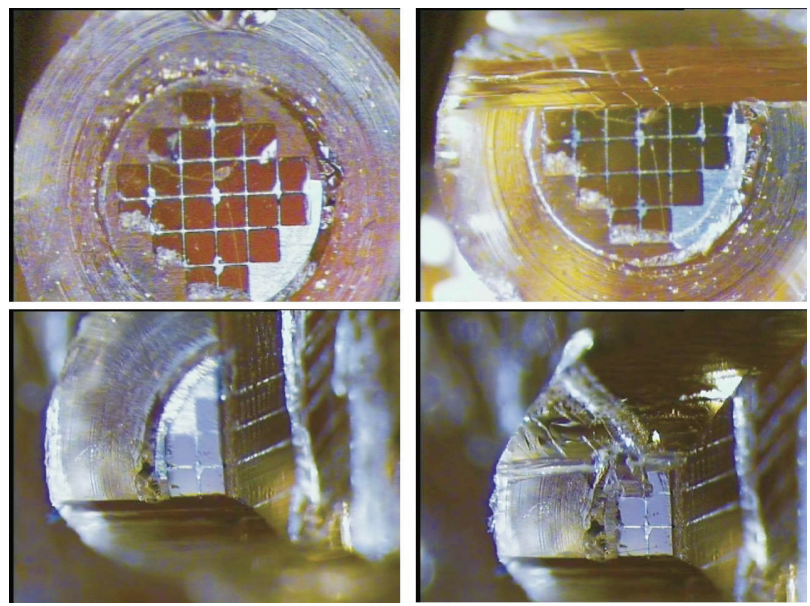

図 12 ファインダーグリッドをみながらトリミングで細胞エリアを追込む 
顕微鏡像と相関を取りながら電子顕微鏡で観察できる.また， EM PACT2 には専用の高速試料装填システムEM RTS がある. 本システムを組み合わせて用いることで，試料をセットしてから 2.5 秒で凍結ができる．専用の試料ローダーに試料を取り付け た状態で光学顕微鏡観察を行えば，観察後 2.5 秒で試料の凍 結が完了する.

\section{凍結後のアプリケーション2-CEMOVIS, cryo-TEM 法}

次に，ガラス様 (非晶質) に凍結した試料を非晶質状態のま ま凍結切削して cryo-TEM観察するCEMOVIS (Cryo Electron Microscopy Of Vitreous Sections)について述べる. ガラス状 に凍った試料は，トリミングの精度とサイズが良ければ，30nm 〜100nmの連続切片を作製する事が可能である.この時, ト リミングナイフ, 超薄切片作製用のナイフには, ダイヤモン ドを用いると良い。ただし，非晶質の水は $135 \mathrm{~K}\left(-138.15^{\circ} \mathrm{C}\right)$ 以上になると相転移して氷晶を形成してしまう (Dubochet and McDowall 1981). そのため, 凍結切削からcryo-TEM観察 までの全プロセスで厳密な温度管理が必要である。弊社のク ライオミクロトームはウルトラミクロトームEM UC7に凍結切片作 製システムEM FC7を取り付けて用いるものである. 本装置は $-185^{\circ} \mathrm{C} \sim-15^{\circ} \mathrm{C}$ 範囲で任意に温度設定した冷却窒素ガス雰 囲気下で切削を行うことができる. クライオチャンバーの手前 左側に液体窒素プールがあり, そこから生成される冷却窒素 ガスがチャンバー内から常に一定量フローアウトする構造になっ ている. 精密作業と実体顕微鏡観察のためオープントップとなつ ているが，チャンバー内部は常に陽圧になるため，チャンバー 表層で生成される霜がチャンバー内に落ち込みにくく, 長時 間, 快適に作業を行うことができる.しかし cryo-TEM 観察では, 僅かな霜の付着が切片の観察を著しく妨げるため, さらなる防 霜対策としてクライオスフェアという防霜グローブボックスを提案 している.これは, クライオミクロトームのほぼ全体を収納でき る簡易式グローブボックス (図 13) で, EM FC7からフローアウト したガス窒素がクライオスフェア内に充満したのち, クライオスフェ アと机との接続部に設けた隙間からフローアウトする構造になっ ている. さらに, 窒素ガスをクライオスフェア外から積極的に送 り込むことも可能である. 高温多湿な日本においても気候・天 気にかかわらずクライオスフェア内の湿度を10\% 程度に保つこ とができ, 図14のように霜の発生を大いに改善することができる. だが，いずれの環境でも，窒素ガスでパージされたチャンバー 内は非常に乾燥しており, 試料が静電気を帯びやすく, 切削 するといら行為自体も静電気を発生させてしまう。この静電気 により切片の操作が著しく困難になる. そこで, 静電気制御装 置CRIONを用いて除電をしながら切削を行い(図 15), さらに, 薄いため脆く弱い切片を物理的な圧着などしないで蓄電機能 により,グリッド上の支持膜への静電的接着を行う.

CEMOVIS では凍結固定法の利点に加え, 電子染色を行 わず生体分子由来の主に位相コントラストによって観察を行う ため，生体分子の性質を反映した像が得られる(図 16, 17). 適切な位相コントラストを得るためには, 切片が薄いほど良く, 厚さ $30 \mathrm{~nm} \sim 40 \mathrm{~nm}$ 程度の切片を作製したい. この時，トリミン グのサイズ，特に幅が重要で，ダイヤモンド製のトリミングナ イフを用い， $50 \mu \mathrm{m}$ 以下の幅まで精密に加工すると良いだろ う.これにより, 無染色でも高いコントラストで膜構造などを観 察することが出来る. しかし, 生きた状態に近い像が得られる CEMOVISだが，弾性のない氷をドライ切削することに起因す
るCEMOVIS 特有のアーティファクトも存在する. ナイフマー ク, クレバス, チャター, および圧縮などである (Amoudi et.al. 2002, 岩崎ら 2012). その一方, 切片を作製した残りの試料断 面にはこのようなアーティファクトは生じにくく構造保存性が高い. そこで, 著者らは現在この断面を cryo-SEM で観察する手法に 取り組んでいる．組織全体への，よりワイドな領域の観察には,

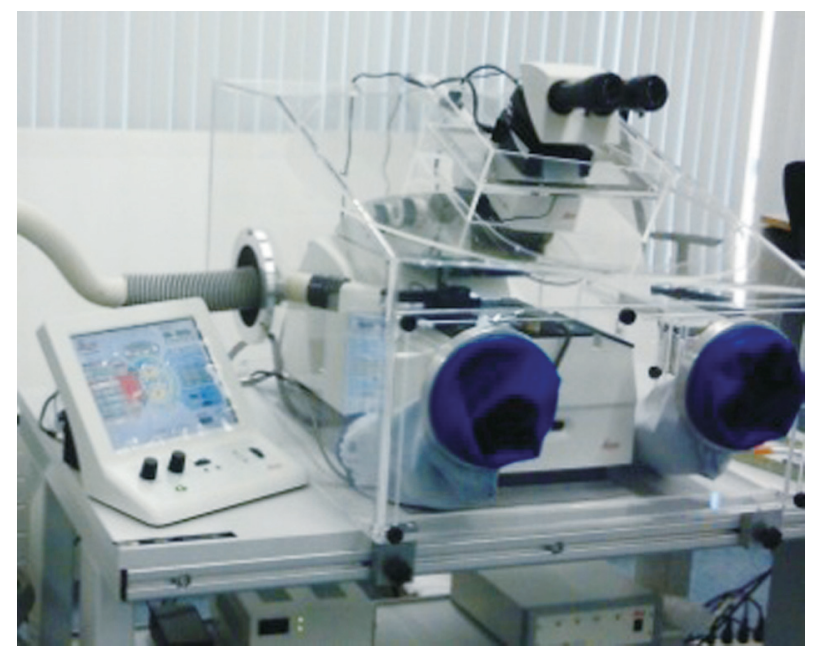

図 13 UC7 及びFC7クライオミクロトームシステムとクライオスフェア概観

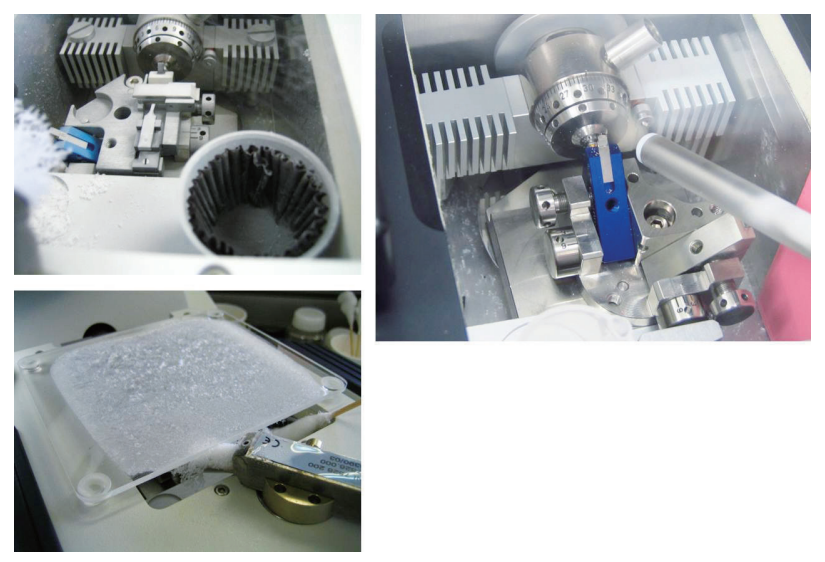

図 14 凍結切削中の霜の有無

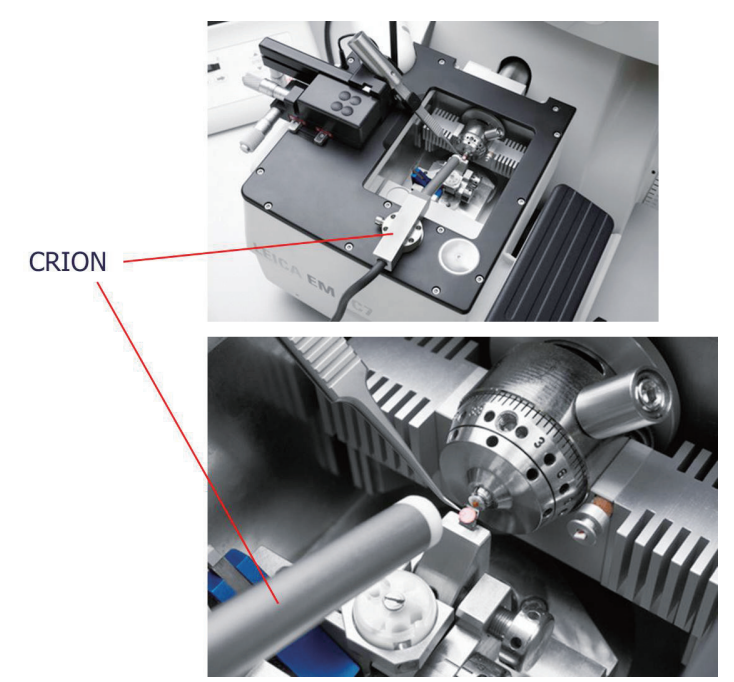

図 15 マイクロマニュピレーターシステムとCRIONによる 静電気を用い た切片回収テクニック 
優れた方法である. 前述のEM FC7のチャンバー側面に試料 を取り出すための穴を開けたEM FC7Tから真空トランスファー 装置EM VCT100を用いて，切削した試料を冷却状態のまま cryo-SEMに搬送することができる(図 18)．cryo-SEMのステー ジ温度をコントロールして試料をわずかにエッチングすれば, 二次電子像を用いて細胞構造を観察することができる. また, EM VCT100をシヤトルシステムとして使う事で，一度観察した 試料を再びEM FC7T や他の前処理装置に搬送して戻すことも できるので, 切削と観察を繰り返して目的部位を探すことも可 能である (伊藤ら 2012, 西野ら 2012) .

\section{まとめ}

最新の高圧凍結技法について，装置とその原理及び使用 方法を解説した. さらに, 凍結後の試料作製技術を凍結置換

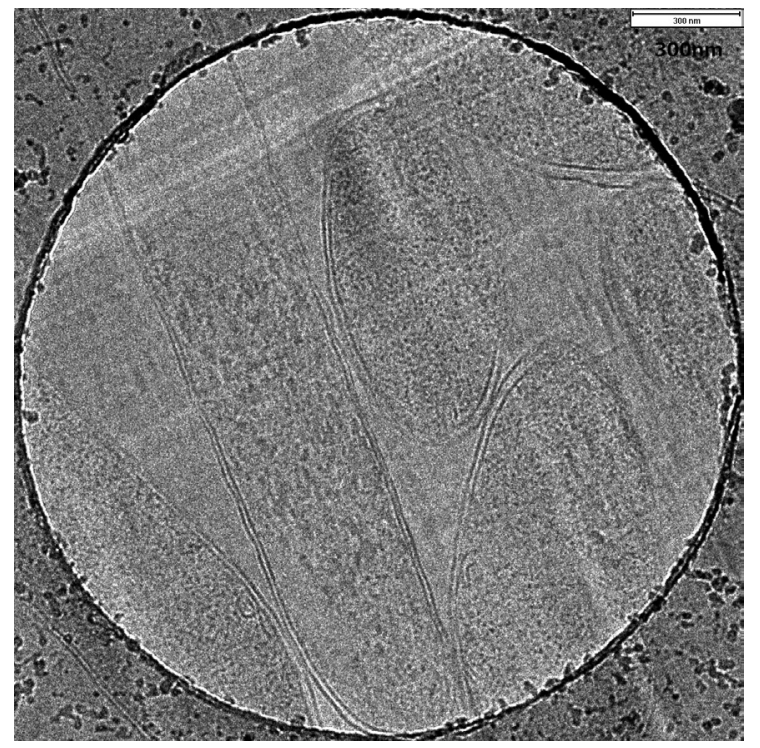

図 16 大腸菌のCEMOVIS. 高圧凍結後, 凍結超薄切片作製 $(30 \mathrm{~nm})$
法とCLEM， cryo-TEM法としてCEMOVISに加え，筆者らが 最近取り組んでいるcryo-SEM 法を紹介した。本報告が皆様 の研究の参考になれば幸いである.

\section{引用文献}

Al-Amoudi, A., Dubochet, J., Studer, D., (2002) Amorphous solid water produced by cryosectionong of crystalline ice at 113K. J Microscopy 207:pp.146-153

Dubochet, J., McDowall, A. W. (1981) Vitrification of pure water for electron microscopy. J Microscopy 124: RP3-RP4.

Dubochet, J., Adrian, M., Chang, J. J., Homo, J. C., Lepault, J., McDowall, A. W., and Schultz, P. (1988) Cryo-electron microscopy of vitrified specimens. $Q$ Rev Biophys 21: 129-228.

Dahl, R. and Staehelin, L. A. (1989) High-pressure freezing for the preservation of biological structure: Theory and practice. J Electron Microsc Tech 13: 165-174.

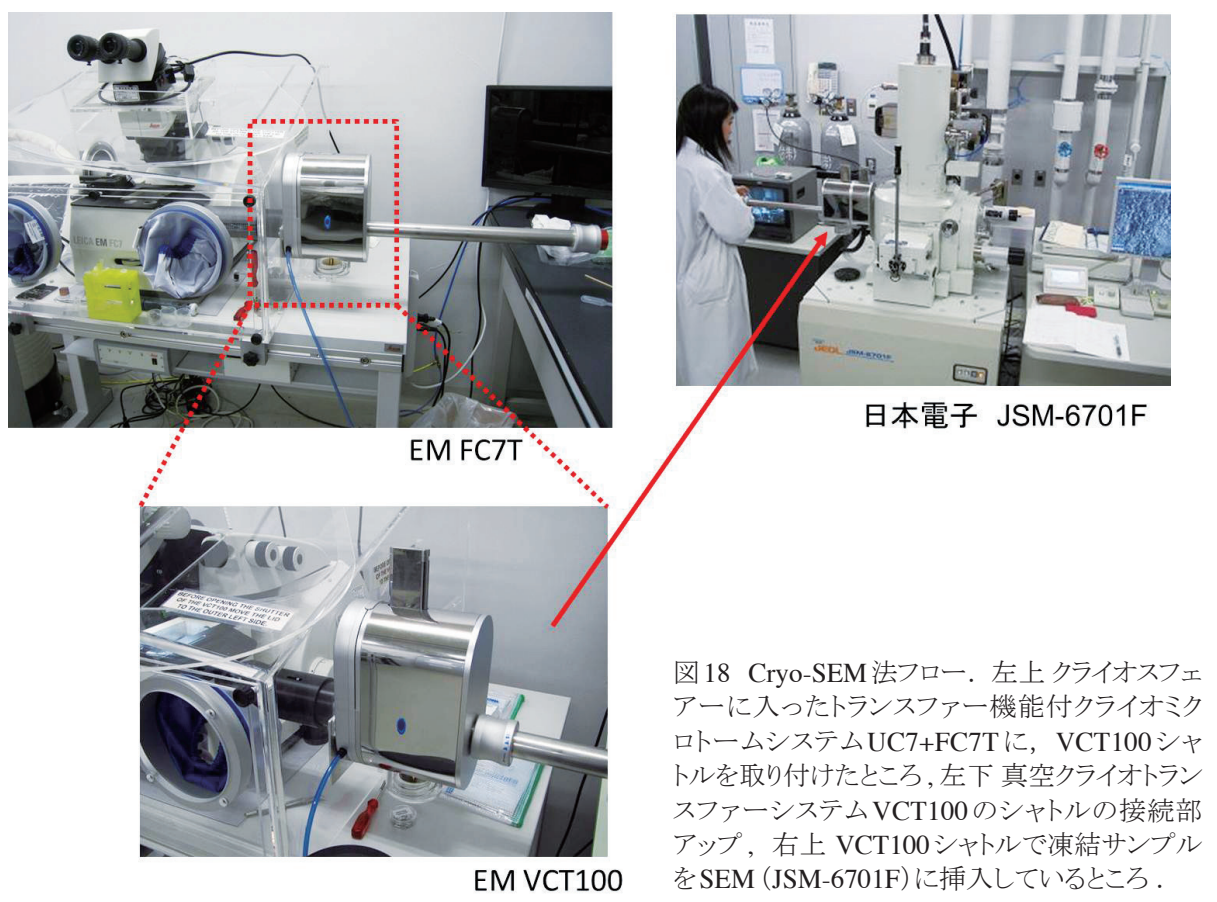


Heuser, J. E., Reese, T. S., Dennis, M. J., Jan, Y., Jan, L., and Evans, L. (1979) Synaptic vesicle exocytosis captured by quick freezing and correlated with quantal transmitter release. J Cell Biol 81: 275-300.

伊藤喜子, 宮澤淳夫 (2010) クライオ電子顕微鏡法. 実験医学 28: 3944.

伊藤喜子, 西野有里, 宮澤淳夫 (2012) 日本顕微鏡学会第56回シンポ ジウム 要旨集 pp 46-49.

岩崎憲治, 宮崎直幸, 伊藤喜子, 高木淳一 (2012) CEMOVI試料作製 法, 顕微鏡 47: 44-50.

Kanno, H., Speedy R. J., and Angell, C. A. (1975) Supercooling of water to $-92^{\circ} \mathrm{C}$ under pressure, Science $189: 880-881$.

Leunissen, J. L., and Yi, H. (2009) Self-pressurized rapid freezing (SPRF): a novel cryofixation method for specimen preparation in electron microscopy. J Microsc 235: 25-35.

Moor, H. (1987) Theory and practice of high pressure freezing. In: Cryotechniques in Biological Electron microscopy, Steinbrecht, R.A., Zierold, K. (eds), Springer-Verlag, Berlin pp 175-191.

西野有里, 伊藤喜子, 宮澤淳夫(2012) 日本顕微鏡学会第56回シンポ ジウム 要旨集 pp 50-53.

Osumi, M. (2012) Visualization of yeast cells by electron microscopy. $J$ Electron Microsc (Tokyo) 61: 343-365.

Resch, G. P., Brandstetter, M., Pickl-Herk, A. M., Königsmaier, L., Wonesch, V. I., and Urban, E. (2011) Immersion freezing of biological specimens: rationale, principles, and instrumentation. Cold Spring Harb Protoc 2011: pdb-top118.

Sitte, H., Edelmann, L., and Neumann, K. (1987) Cryofixation Without Pretreatment at Ambient Pressure. In: Cryotechniques in biological electron microscopy, Steinbrecht, R., Zierold, K. (eds), Springer Berlin Heidelberg, pp 87-113.

Studer, D., Michel, M., and Müller, M. (1989) High pressure freezing comes of age. Scanning Microsc Suppl 3: 253-268.

菅沼龍夫 (1997) 高圧凍結置換法. 電子顕微鏡 32: 110-112.

Verkade, P. (2009) Moving EM: the Rapid Transfer System as a new tool for correlative light and electron microscopy and high throughput for high-pressure freezing. J Microsc 230: 317-328.

Verkade, P. (2005) Correlative Light and Electron Microscopy with High Time Resolution and Ultrastructural Preservation. Microsc Microanal 11 (Suppl 2): 144-145.

Received: 3 February 2013 